\title{
Endogenous Brain-Derived Neurotrophic Factor and Neurotrophin-3 Antagonistically Regulate Survival of Axotomized Corticospinal Neurons In Vivo
}

\author{
Klaus M. Giehl, ${ }^{1}$ Stephan Röhrig, ${ }^{1}$ Henk Bonatz, ${ }^{1}$ Martin Gutjahr, ${ }^{1}$ Britta Leiner, ${ }^{1}$ Ilse Bartke, ${ }^{2}$ Qiao Yan, ${ }^{3}$ \\ Louis F. Reichardt, ${ }^{4}$ Carey Backus, ${ }^{4}$ Andrew A. Welcher, ${ }^{3}$ Kathrin Dethleffsen, ${ }^{5}$ Pedro Mestres, ${ }^{1}$ and \\ Michael Meyer ${ }^{5}$ \\ 1 University of Saarland, Department of Anatomy, 66421 Homburg/Saar, Germany, ${ }^{2}$ Pharma Research Penzberg, Roche \\ Diagnostics GmbH, Department of Cell Biology, 82372 Penzberg, Germany, ${ }^{3}$ Amgen, Thousand Oaks, California \\ 91320-1799, ${ }^{4}$ Department of Physiology and Howard Hughes Medical Institute, University of California, San Francisco, \\ California 94143, and 5Max-Planck-Institue of Neurobiology, 82152 Martinsried, Germany
}

Neuronal growth factors regulate the survival of neurons by their survival and death-promoting activity on distinct populations of neurons. The neurotrophins nerve growth factor (NGF), brain-derived neurotrophic factor (BDNF), and neurotrophin-3 (NT-3) promote neuronal survival via tyrosine kinase (Trk) receptors, whereas NGF and BDNF can also induce apoptosis in developing neurons through $\mathrm{p} 75^{\mathrm{NTR}}$ receptors in the absence of their respective Trk receptors. Using mutant mice and inactivation of neurotrophins and their receptors with antibodies in rats, we show that endogenous NT-3 induces death of adult BDNF-dependent, axotomized corticospinal neurons (CSNs). When NT-3 is neutralized, the neurons survive even without BDNF, suggesting complete antagonism. Whereas virtually all unlesioned and axotomized CSNs express both trkB and trkC

Neurotrophins comprise a family of closely related neurotrophic factors expressed in target tissues of neurons and in the central and peripheral nervous systems. Four neurotrophins have been identified in rodents: nerve growth factor (NGF), brain-derived neurotrophic factor (BDNF), neurotrophin-3 (NT-3), and neurotrophin-4/5 (NT-4/5) (Lewin and Barde, 1996). The biological effects of these factors are mediated by the common neurotrophin receptor $\mathrm{p} 75^{\mathrm{NTR}}$ and the tyrosine kinase (trk) family receptors with NGF binding TrkA, BDNF and NT-4/5 binding TrkB, and NT-3 binding TrkC (Barbacid, 1995). At high concentrations, NT-3 can also stimulate TrkA and TrkB as nonpreferred receptors (Davies et al., 1995; Ryden and Ibanez, 1996). Promotion of neuronal survival is one of the most prominent physiological functions of the neurotrophins (Barbacid, 1995). It has been shown, though, that NGF and BDNF can also induce neuronal

\footnotetext{
Received Aug. 2, 2000; revised Feb. 15, 2001; accepted Feb. 23, 2001.

This work was supported by grants from the Deutsche Forschungsgemeinschaft (SFB 530 C6 to K.M.G. and DFG Gi 271/3-1 to K.M.G. and P.M.). We thank Birgit Kunkel and Andrea Steinberg for excellent technical assistance, Dr. Miriam Bibel for advice on the phosphorylation assay and gift of reagents, and Dr. Georg Dechant for providing the TrkC-expressing cell line. We are also grateful to Drs. Y.-A. Barde and $\mathrm{H}$. Thoenen for helpful suggestions and discussion and Dr. Clare J. MenzelDowling for helpful discussion and proofreading of the manuscript. NT-3 has been generously supplied by Amgen/Regeneron partnership.

Correspondence should be addressed to Dr. Klaus Giehl, University of Saarland, Department of Anatomy, 66421 Homburg/Saar, Germany. E-mail: k.giehl@rz. uni-sb.de.

Copyright (C) 2001 Society for Neuroscience $\quad 0270-6474 / 01 / 213492-11 \$ 15.00 / 0$
}

mRNA, p75 is barely detectable in unlesioned CSNs but strongly upregulated in axotomized CSNs by day 3 after lesion, the time point when cell death occurs. Blocking either cortical TrkC or $\mathrm{p} 75^{\mathrm{NTR}}$ receptors alone prevents death, indicating that the opposing actions of NT-3 and BDNF require their respective Trk receptors, but induction of death depends on $\mathrm{p} 75^{\mathrm{NTR}}$ cosignaling. The results show that neuronal survival can be regulated antagonistically by neurotrophins and that neurotrophins can induce neuronal death in the adult mammalian CNS. We further present evidence that signaling of tyrosine kinase receptors of the trk family can be crucially involved in the promotion of neuronal death in vivo.

Key words: neuronal death; neurotrophins; TrkC; p75; cortex; lesion

death via $75^{\text {NTR }}$ receptors in developing neurons (Dechant and Barde, 1997; Kaplan and Miller, 1997; Bamji et al., 1998).

Until recently it was thought that neuronal survival is regulated by the limited access to survival-promoting factors (Lewin and Barde, 1996). This hypothesis was modified by the findings that developmental death is induced via $\mathrm{p} 75^{\mathrm{NTR}}$ in retinal neurons by endogenous NGF (Frade et al., 1996, 1997; Frade and Barde, 1998) and in sympathetic neurons by BDNF (Bamji et al., 1998). Thus, a neurotrophin can promote neuronal survival or death, depending on which receptor it activates. In this concept, Trk receptors mediate survival signals, whereas $\mathrm{p} 75^{\mathrm{NTR}}$ mediates the death signal in the absence of the respective Trk receptor (Dechant and Barde, 1997; Kaplan and Miller, 1997; Bamji et al., 1998). However, it is not known whether survival of the neurons that die because of a neurotrophin is promoted by another endogenous neurotrophin and whether neurotrophins can induce death of mature neurons at all. The present study approaches this question in the corticospinal system.

The corticospinal system constitutes a major central motor projection to spinal cord motoneurons (Nudo and Masterton, 1990). Approximately half of adult rat corticospinal neurons of the sensory motor cortex (CSNs) die after axotomy at internal capsule levels (Fig. 1) (Giehl and Tetzlaff, 1996; Bonatz et al., 2000). Virtually all CSNs express trkB and trkC and are rescued from axotomy-induced death by high-dose BDNF and NT-3 treatment (Giehl and Tetzlaff, 1996), indicating that these factors play a role in their survival regulation. Indeed, endogenous 

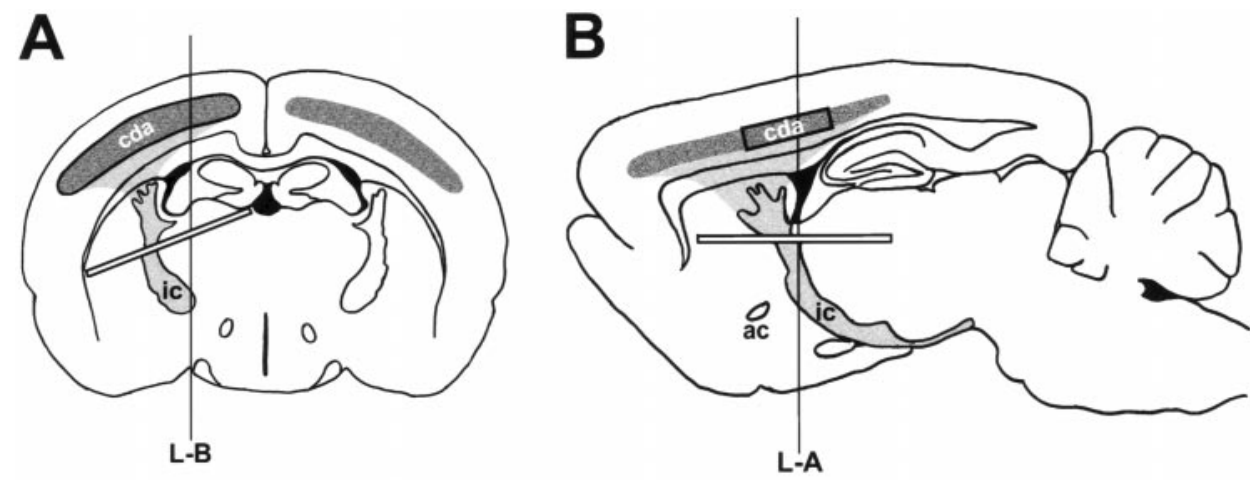

$=$ area of corticospinal neurons

= axonal projection of corticospinal neurons

= extent of the internal capsule lesion
Figure 1. Schematic illustrating the corticospinal lesion model. The cell death area ( $c d a$; outlined in black) is the area where death of CSNs is regularly observed after ICL. The quantitative survival data were obtained from the cda. Indicated are the localization of CSNs, their projection pathway, and the extent of the ICL. $i c$, Internal capsule; $a c$, anterior commissure. $A$, Frontal plane of the forebrain. Axotomy side is left, control side right. $L-B$ is the lateral level from which the sagittal plane in $B$ is taken. $B$, Sagittal plane of the brain on the axotomy side. $L-A$ is the frontal level from which $A$ is taken. CSNs (sensory motor cortex) are localized in the posterior three quarters of the mediodorsal areas of corticospinal neurons (Miller, 1987; Bonatz et al., 2000). The corticospinal neurons of the anterior quarter belong to the medial prefrontal and the supplementary motor cortex (Miller, 1987; Bonatz et al., 2000).
BDNF is a crucial survival factor for most axotomized CSNs (Giehl et al., 1998). However, the dose of NT-3 that completely rescues CSNs if applied alone (Giehl and Tetzlaff, 1996) results only in partial survival if endogenous BDNF is simultaneously neutralized (Giehl et al., 1998). In addition, NT-3 infusions increase BDNF mRNA expression in cortical layers 2-4 (Schütte et al., 2000). These findings suggest that the effects of high-dose NT-3 treatment (Giehl and Tetzlaff, 1996) are not attributable to the activation of TrkC alone but rather result from stimulation of endogenous BDNF protection of lesioned CSNs. They may, therefore, not reflect the physiological function of NT-3 for CSNs.

The present study shows that endogenous NT-3 promotes the death of all BDNF-dependent CSNs, indicating that endogenous neurotrophins can antagonistically regulate neuronal survival in the adult mammalian CNS. Activation of both $\mathrm{p} 75^{\mathrm{NTR}}$ and TrkC receptors is required for this effect of NT-3, suggesting that cosignaling by a tyrosine kinase receptor and a tumor necrosis factor receptor family member is essential for the promotion of CSN death.

\section{MATERIALS AND METHODS}

Operation procedure. Experimental procedures and maintenance of animals were approved by the local Animal Care Committee according to the German law regulating the experimental use of animals. Five- to 9-week-old mice of both sexes of a BDNF (Korte et al., 1995) and NT-3 (Airaksinen et al., 1996) mutant strain and male Sprague Dawley rats weighing 190-330 gm were used. The procedure and stereotaxic coordinates for the operations, internal capsule lesion (ICL), confirmation of the axotomy of CSNs after ICL, intracortical delivery of solutions (only for rats), and the determination of the lesion and cell death areas have been described elsewhere (Giehl and Tetzlaff, 1996; Bonatz et al., 2000). In brief, to distinguish CSNs from other cortical layer 5 neurons, they were retrogradely labeled by fluorescence tracer injections to the corticospinal tracts at cervical spinal cord levels $\mathrm{C} 4 / 5$ before axotomy. Fast Blue (FB) $(2 \%$ in $0.2 \%$ DMSO) and/or a rhodamine tracer mixture (RDX) (15\% rhodamine dextran 10,000, 10\% rhodamine dextran 3000, and $10 \%$ rhodamine-b-isothiocyanate in $0.2 \%$ DMSO) were used as tracers. FB was used as the primary tracer in all groups that received ICL. One to 2 weeks after FB injection, CSNs of one side of the brain were axotomized by ICL. ICL creates a horizontal, circle-shaped cut through the entire internal capsule (Bonatz et al., 2000) through which CSNs send their axons to their spinal cord targets (Fig. 1) (Nudo and Masterton, 1990). As determined by the injection of RDX at spinal cord level C3/4 immediately after the lesion, ICL results in axotomy of all corticospinal neurons of the sensory motor cortex (CSNs) of the lesion side in rats (Giehl and Tetzlaff, 1996; Bonatz et al., 2000) and in mice
(Fig. 2). In the rat treatment groups, Alzet 2001 osmotic minipumps were implanted in the same operation session for intracortical delivery of solutions. For this delivery, a 30 gauge steel cannula connected to the minipump via a silicone tube was implanted intraparenchymally into the lesion area of the cortex on the lesion side.

Intracortically infused solutions. The osmotic minipumps delivered either NT-3-neutralizing mouse monoclonal NT-3 antibody of the IgG1 subclass (anti-NT-3; $1 \mathrm{mg} / \mathrm{ml}$ in P1 buffer) (Barres et al., 1994), the BDNF-neutralizing rabbit affinity-purified BDNF antibody RAB (antiBDNF; $1 \mathrm{mg} / \mathrm{ml}$ in PBS) (Yan et al., 1997b; Giehl et al., 1998), a combination of anti-NT-3 and anti-BDNF (1 mg/ml each in P1 buffer), p $75^{\text {NTR }}$-blocking monovalent Fab fragments of IgG of the rabbit REX antibody against p75 ${ }^{\mathrm{NTR}}$ (REX-Fab; $150 \mu \mathrm{g} / \mathrm{ml}$ or $300 \mu \mathrm{g} / \mathrm{ml}$ in P2 buffer) (Weskamp and Reichardt, 1991), protein A column-purified IgG of the rabbit anti-TrkC antibody TC89 (TC89; 2, 4, 8, or $16 \mathrm{mg} / \mathrm{ml}$ in P2 buffer), human recombinant NT-3 $(0.5 \mathrm{mg} / \mathrm{ml}$ in PBS), rabbit anti-turkey IgG (RIgG; Sigma, St. Louis, MO; 1 or $16 \mathrm{mg} / \mathrm{ml}$ in PBS; as control for anti-BDNF and TC89), mouse IgG1 (MIgG1; Sigma; $1 \mathrm{mg} / \mathrm{ml}$ in P1buffer; as control for anti-NT-3), monovalent Fab fragments of rabbit IgG (RFab; Jackson ImmunoReseach, West Grove, PA; $150 \mu \mathrm{g} / \mathrm{ml}$ or 1 $\mathrm{mg} / \mathrm{ml}$ in P2 buffer; as control for REX-Fab), $20 \mathrm{~mm}$ PBS (as control for RIgG and NT-3), a 1:1 mixture of PBS and $10 \mathrm{~mm}$ potassium phosphate/ $150 \mathrm{~mm}$ sodium chloride buffer (P1 buffer; as control for M IgG1), or 2.5 $\mathrm{mm}$ potassium phosphate $-20 \mathrm{~mm}$ disodium phosphate $-120 \mathrm{~mm}$ sodium chloride buffer (P2 buffer; as control for RFab and as buffer control for TC89). All solutions contained $50 \mathrm{U} / \mathrm{ml}$ penicillin-streptomycin and were infused at a rate of $1 \mu \mathrm{l} / \mathrm{hr}$ for $7 \mathrm{~d}$. The respective neutralizing and blocking properties of anti-NT-3 (Barres et al., 1994), anti-BDNF (Yan et al., 1997b; Giehl et al., 1998), and REX-Fab (Weskamp and Reichardt, 1991) have been demonstrated elsewhere. For TC89, see "Characterization of TC89." The correct generation of the REX-Fab fragments has been confirmed in protein-gels (data not shown). The intracortical diffusion area of the infused antibodies was controlled by immunohistochemistry and was never $<4 \mathrm{~mm}$ in diameter, i.e., the CSNs of the cell death area (see "Analysis of Axotomy and Survival") were located within the diffusion areas.

Characterization of TC89. The TC89 antiserum was generated in rabbit against a fusion protein of trpE (Rimm and Pollard, 1989) linked to amino acids 127-429 of the extracellular domain of rat TrkC, expressed in Escherichia coli. Western blot analyses of various recombinant Trk proteins (Yan et al., 1997a) indicated that the TC89 antisera was specific for TrkC (see Fig. 5B). TC89 results in TrkC-like immunoreactivity in rat brain sections (data not shown). The effects of protein A-purified IgG of TC89 serum on TrkC phosphorylation have been tested in TrkCtransfected NIH3T3 cells essentially as described (Tsoulfas et al., 1996). TrkC phosphorylation after $5 \mathrm{~min}$ of $100 \mathrm{ng} / \mathrm{ml} \mathrm{NT}-3$ served as positive control. TrkC phosphorylation was completely abolished by TC89 treatment $(16 \mu \mathrm{g} / \mathrm{ml}$ added for $10 \mathrm{~min}$ starting $5 \mathrm{~min}$ before NT-3 addition) (see Fig. $5 C$ ). Treatment with TC89 IgG alone had no effect on TrkC phosphorylation.

TrkB phosphorylation. Tyrosine phosphorylation of TrkB was assessed in $2 \times 2 \times 1.5 \mathrm{~mm}$ blocks of cortex of rats that had been treated with 
A
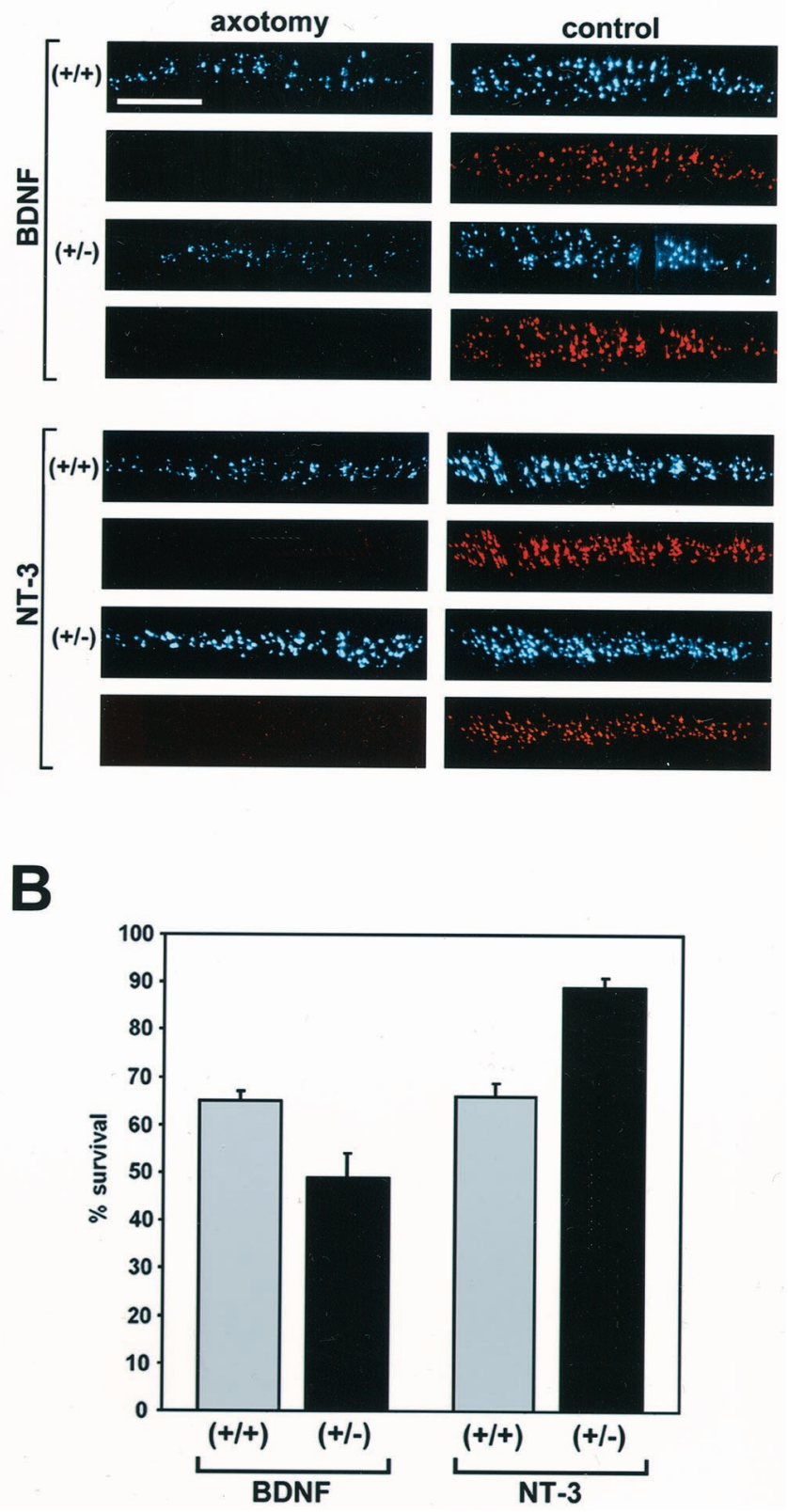

Figure 2. Death of axotomized CSNs is increased in BDNF mutant mice but almost completely prevented in NT-3 mutant mice. A, Top pairs of the photomicrographs show FB-labeled CSNs of representative animals of each experimental group, 1 week after axotomy. Axotomy induces death in both BDNF $(+/+)$ and NT-3 $(+/+)$ animals (wild-type control groups). This death is increased in BDNF (+/-) animals and almost completely prevented in NT-3 (+/-) animals. The bottom pair of photomicrographs in each experimental group shows the same sections under illumination for RDX (red label) which has been applied after ICL to confirm the axotomy. This results in RDX labeling of unlesioned CSNs but does not label axotomized CSNs. On the control side, virtually all CSNs are double-labeled with FB and RDX. On the axotomy side, FB-labeled CSNs are not labeled with RDX, indicating the completeness of axotomy. Scale bar, $0.5 \mathrm{~mm}$. B, Quantification of the survival of axotomized mice CSNs (indicated is mean survival \pm SEM). One-third of the CSNs die in the control groups of the BDNF $(n=9)$ and NT-3 $(n=$ 12) knock-out strains. This death is increased in BDNF $(+/-)$ animals $[n=9 ; p<0.01$ vs control as determined by (adb) NKT] and almost completely prevented in NT-3 $(+/-)$ animals $[n=10 ; p<0.01$ vs control adb NKT].
NT-3 (500 ng/ $\mu$ l in vehicle, $10 \mu \mathrm{l})$ or vehicle (20 mM PBS, $10 \mu \mathrm{l})$ for 30, 60,120 or $360 \mathrm{~min}$. Tissue processing was as described (Tsoulfas et al., 1996) with the following modifications. One milliliter of extract was incubated overnight with $2 \mu \mathrm{g}$ of the tyrosine phosphate-specific antibody 4G10 (Upstate Biotechnology, Lake Placid, NY) at $4^{\circ} \mathrm{C}$. Protein A Sepharose was added and bound for $2-3 \mathrm{hr}$ at $4^{\circ} \mathrm{C}$. Western blots were detected using a previously generated and characterized TrkB antiserum (trkBMBSKLH; Offenhäuser et al., 1995).

$R T$-PCR of trkC isoforms. Total RNA was extracted from cortical tissue blocks $(2 \times 2 \times 1.5 \mathrm{~mm})$ of rats that had received NT-3 $(500 \mathrm{ng} / \mu \mathrm{l}$ in vehicle at a rate of $1 \mu \mathrm{l} / \mathrm{hr}$ ) or vehicle (20 mM PBS at a rate of $1 \mu \mathrm{l} / \mathrm{hr}$ ) for 3 or $7 \mathrm{~d}$ before analysis. Reactions were performed essentially as described before (Offenhäuser et al., 1995) using primers on both sides of the kinase insert. The $3^{\prime}$ primer was modified to CTCCACACATCACTCTCTGTG. To control for linear amplification, reactions of 26 and 30 cycles were run.

Tissue processing. Seven days after tracer application (unlesioned animals) or after ICL (lesioned animals), the animals were killed by an overdose of sodium pentobarbital and transcardially perfused with PBS followed by $4 \%$ paraformaldehyde (PFA) solution. The brains were post-fixed in $4 \%$ PFA ( $1 \mathrm{hr}$ ), cryoprotected in $20 \%$ sucrose in PBS (12 hr), frozen, and cut into $20 \mu \mathrm{m}$ cryostat serial coronal sections. In mice, every second section was collected for cell counts. In mice that received an ICL, the remaining sections were collected separately for in situ hybridizations (ISHs) (confirmation of neurotrophin receptor expression, data not shown). In rats, every fifth section was collected for cell counts, and the remaining sections were collected separately for ISH and other procedures. For the semiquantitative ISH on rat brain sections, only sections from the center of the cell death area (see "Analysis of survival") were used.

Rat and mouse corticospinal systems. The developmental principles for establishing the corticospinal projection do not differ between rat and mice (O'Leary and Koester, 1993; Uematsu et al., 1996). Rats have more and larger corticospinal neurons than mice but of very similar localization (Nudo and Masterton, 1990; Nudo et al., 1995). Detailed mapping (Bonatz et al., 2000) revealed that mutant and wild-type mice have the same area-specific localization of corticospinal neurons as rats (Miller, 1987; Bonatz et al., 2000), displaying three major areas of localization: (1) the sensory motor cortex, (2) the supplementary motor and medial prefrontal cortex, and (3) the somatosensory cortex. All corticospinal neurons of the sensory motor cortex (CSNs) are axotomized by ICL (Fig. 2). In contrast, ICL does not result in complete axotomy of corticospinal neurons of the other areas which have, therefore, not been considered in this study. Analyses of trkB, trkC, and p75 mRNA expression in wildtype and neurotrophin mutant mice (data not shown) revealed that their unlesioned and axotomized CSNs show identical expression patterns as rats and that p75 is upregulated also in mice after ICL. Thus, the organization and neurotrophin dependencies of both rat and mouse corticospinal systems seem to be very similar.

Analysis of survival. The number of CSNs was assessed by blinded cell counts of every second section collected for cell counts, i.e., every fourth section of the mice and every 10th section of the rat brains were quantified. The criterion for a CSN was a Tracer-filled pyramidal-shaped profile $>4 \mu \mathrm{m}$ (rats) or $>3 \mu \mathrm{m}$ (mice) in diameter (Giehl and Tetzlaff, 1996; Bonatz et al., 2000). Both in mice and in rats, all CSNs of the lesion side are axotomized by ICL (see operation procedure). The central 2.8 $\mathrm{mm}$ in rats and the central $1.6 \mathrm{~mm}$ in mice of the CSN area were defined as "cell death area" (Bonatz et al., 2000), the area where dying CSNs were regularly observed in both lesion-only animals (rats and wild-type mice) and lesioned animals that were treated with control solutions (rats). This area was used as an anatomical mask for the other experimental groups to obtain the respective survival data. Both in mice and in rats, the anterior end of the cell death area is at the frontal plane of the anterior pole of the anterior commissure (Fig. 1). Within the cell death area, percentage of survival is defined as "number of FB-labeled CSNs on the lesion side/number of FB-labeled CSNs contralateral to the lesion side $\times 100 \%$." The data are based on a total of over 380,000 cells counted in rats and over 310,000 cells counted in mice. One-way ANOVA which was followed by a post hoc Newman-Keuls test (NKT) and a post hoc Fisher's least significance difference test (FLSD) was used to determine the statistical significance of differences in survival among the individual experimental groups. As determined separately for mice and rats, the differences in the mean values among the individual experimental groups were highly significant using ANOVA $(p<0.001)$. For the respective NKT and FLSD, see Figure legends. 
Analysis of neurotrophin receptor expression. Abundant TrkC immunoreactivity has been shown in several cortical layers, including layer 5 (Miller and Pitts, 2000; Pitts and Miller, 2000), and p75 immunoreactivity is inducible by several stimuli including lesions in many cortical areas (Botchkina et al., 1997; Roux et al., 1999; Shi and Mocchetti, 2000) and after axotomy in spinal motoneurons (Wu et al., 1993). To examine whether the respective proteins localize to unlesioned and/or axotomized corticospinal neurons, we performed immunohistochemistry for the neurotrophin receptors on sections from animals that received unilateral axotomy of FB-labeled CSNs. Satisfactory cortical immunolabeling was only possible with mild fixation and free-floating techniques that are not compatible with the maintenance of FB labeling of CSNs. We, therefore, analyzed neurotrophin receptor expression with an oligonucleotide in situ hybridization technique that has previously been shown to be compatible with neuronal FB label (Giehl and Mestres, 1995; Giehl et al., 1998). Oligonucleotide probes for the individual mRNAs were labeled with ${ }^{35}$ S-dATP (DuPont NEN, Boston, MA), using terminal deoxynucleotide transferase (Life Technologies, Gaithersburg, MD). The p75 probe used for the semiquantitative in situ hybridizations reported in this paper was complementary to the nucleotides $932-971$ of the rat p75 mRNA (Radeke et al., 1987). We repeated the experiments with a probe complementary to nucleotides $1809-1848$ of rat p75 mRNA (Radeke et al., 1987), and the results were essentially the same (data not shown). The trkC probe (Giehl and Tetzlaff, 1996) was complementary to base pairs 2109-2272 (except 2134-2250) and bridged the insertion site (2134-2250) of the TrkC tyrosine kinase domain (Valenzuela et al., 1993). Posthybridization washes and autoradiography were performed as described elsewhere (Giehl and Mestres, 1995). At the high stringency conditions used for the hybridizations and the posthybridization washes (Giehl and Mestres, 1995), the trkC probe is highly specific for the noninserted full-length trkC isoform (Giehl and Tetzlaff, 1996).

Quantification of $m R N A$ expression. The procedure used for the quantification of mRNA expression in CSNs is described elsewhere (Giehl et al., 1998). For the calculation of the percentage of CSNs expressing the respective mRNA, mRNA levels in CSNs are expressed as an $x$-fold of background grain density (see below). Because expression of p75 and trkC mRNA in reactive glia cannot be excluded in brain tissue after experimental manipulation, background measurements were performed over the slide. The brain tissue itself can have an unspecified chemographic effect on the grain density, which results in higher background values over the tissue than over the slide (Rogers, 1979; McCabe et al., 1989). To account for this chemographic effect, we determined a correction factor for the above slide background measurements as follows: background measurements have been performed over the slide and the cortex of autoradiographies obtained from the competition tests for the respective probes. Because autoradiographies of competition tests did not contain positive label, these measurements assess solely the chemographic component of the brain tissue without including the glial signal. From these measurements, we calculated a slide-to-brain ratio for each probe (1.6 for p75 and 1.66 for trkC). These slide-to-brain-ratios have then been used as correction factor for the background measurements of the p75 and trkC ISH, respectively. The procedure and rationale for determining the criterion for a CSN expressing the respective mRNA (threshold in all cases more than threefold corrected background) has been described elsewhere (McCabe et al., 1989; Giehl et al., 1998). The data are based on a total of $>25,000$ cells. As determined separately for p75 and trkC, the differences in the mean values among the individual experimental groups were highly significant using ANOVA $(p<0.001)$. For the respective NKT and FLSD, see Figure legends.

\section{RESULTS}

The gross anatomy of the corticospinal system is not altered in young adult BDNF and NT-3 heterozygotes

The developmental role of BDNF and NT-3 for CSNs was analyzed in young adult BDNF and NT-3 mutant mice. For this analysis, it is necessary to specifically label CSNs by injecting retrograde tracers to the corticospinal tract of the spinal cord. Because homozygous BDNF (Ernfors et al., 1994a; Jones et al., 1994) and NT-3 knock-out mice (Ernfors et al., 1994b; Farinas et al., 1994; Tessarollo et al., 1994) survive only a few days after birth, and the axonal connectivity of CSNs to the spinal cord develops
Table 1. RDX-labeled CSNs

\begin{tabular}{lll} 
& $(+/+)$ & $(+/-)$ \\
\hline BDNF allele & $5867 \pm 389(n=6)$ & $5773 \pm 683(n=8)$ \\
NT-3 allele & $6033 \pm 446(n=8)$ & $6331 \pm 316(n=8)$
\end{tabular}

Total numbers of RDX-labeled CSNs of one cortical side counted in every fourth section of unlesioned mice of the respective experimental groups. No statistically significant differences could be detected.

between P0 and P20 (Jones et al., 1982; Oudega et al., 1994; Uematsu et al., 1996), only the respective heterozygous $(+/-)$ and wild-type $(+/+)$ animals were analyzed. CSNs were labeled with RDX in 6-week-old mice. Mapping (data not shown) and cell counts (Table 1) of RDX-labeled CSNs did not reveal any changes regarding localization or numbers of CSNs in BDNF or NT-3 $(+/-)$ animals, suggesting that wild-type levels of BDNF and NT-3 are not essential for the developmental regulation of these aspects.

\section{Survival of axotomized CSNs is decreased in BDNF $(+/-)$ and improved in NT-3 (+/-) mice}

To examine the roles of these neurotrophins for mature CSN, we analyzed their response to axotomy in adult mice of these mutant strains. FB-labeled CSNs of 8- to 9-week-old mice were axotomized by an ICL (Fig. 1). One-third of the axotomized CSNs died in the BDNF and NT-3 $(+/+)$ groups within the first week after axotomy (Fig. 2). Death was significantly increased in BDNF $(+/-)$ animals (Fig. 2), indicating that BDNF is a survival factor for axotomized murine CSNs. In contrast, survival of axotomized CSNs was much improved in NT-3 (+/-) mice (Fig. 2), suggesting that endogenous NT-3 promotes CSN death.

\section{Endogenous NT-3 induces death of BDNF-dependent axotomized rat $\mathrm{CSNs}$}

To determine whether the unexpected results in NT-3 $(+/-)$ animals reflect promotion of death by endogenous NT-3 or were attributable to developmental changes caused by the targeted mutation of the NT-3 allele, we acutely reduced NT-3 levels in wild-type albino rats with a monoclonal NT-3 antibody (antiNT-3) (Barres et al., 1994). Anti-NT-3 was continuously infused into the lesioned cortex for $7 \mathrm{~d}$ starting immediately after ICL, which resulted in complete rescue of FB-labeled CSNs from axotomy-induced death (Fig. 3). Thus, endogenous NT-3 induces death of axotomized CSNs. The majority of axotomized rat CSNs depend on endogenous BDNF for survival (Giehl et al., 1998). This BDNF-dependent population consists of all CSNs that die after axotomy and, in addition, almost half of those that survive their axotomy (Giehl et al., 1998). Together with the present finding, these data demonstrate that the survival of all CSNs that die after axotomy is antagonistically regulated by endogenous NT-3 and BDNF.

To show whether NT-3 or BDNF is functionally dominant, we simultaneously infused for $7 \mathrm{~d}$ the affinity-purified neutralizing BDNF antibody RAB (anti-BDNF) (Yan et al., 1997b; Giehl et al., 1998) and anti-NT-3 to axotomized CSNs and compared it with the effects of anti-BDNF alone. Anti-BDNF treatment alone caused death of approximately two-thirds of the axotomized CSNs, whereas death was completely prevented by anti-BDNF/ anti-NT-3 treatment (Fig. 3). Thus, BDNF-dependent CSNs survive axotomy in the absence of BDNF if NT-3 is neutralized. 
Figure 3. Survival of axotomized CSNs is antagonistically regulated by endogenous BDNF and NT-3. $A$, FB-labeled CSNs of lesion and control sides of representative animals of control groups [lesion-only (l.o.), mouse IgG1 (MIgG1), and rabbit $\operatorname{IgG}(R \operatorname{Ig} G)]$ and the groups receiving neutralizing neurotrophin antibodies [NT-3 antibody (anti-NT-3), BDNF antibody RAB (anti$B D N F$ ), and anti-NT-3 plus anti-BDNF] 1 week after axotomy. In the control groups, axotomy results in death of many CSNs. This death is completely prevented after anti-NT-3 treatment and strongly increased after anti-BDNF treatment. Simultaneous application of BDNF and NT-3 (anti-NT-3 + anti-BDNF) results in complete survival of axotomized CSNs. Scale bar, 1 mm. B, Quantification of survival of axotomized rat CSNs (indicated is mean survival \pm SEM). The control groups display significant death within the first week after axotomy [1.o. $(n=11)$, PBS $(n=12)$, P1 buffer $(64 \pm 5 \% ; n=5$; data not shown), MIgG1 $(n=4)$, and $\mathrm{RIgG}(1 \mathrm{mg} / \mathrm{ml}$; $n=5)]$. Anti-NT-3 treatment completely prevents this death $[n=7, p<0.01$ vs each control group adb NKT]. In contrast, approximately two-thirds of the CSNs die after anti-BDNF treatment $[n=5, p<0.01$ vs RIgG adb NKT, $p<0.05$ vs 1.o. adb NKT]. Simultaneous antiNT-3 + anti-BDNF treatment completely rescues CSNs $[n=5, p<0.01$ vs all control groups adb NKT], demonstrating that the NT-3mediated death signal is dominant and that virtually all BDNF-dependent CSNs (see Results) underlie an antagonistic survival regulation by BDNF and NT-3. The difference in survival between 1.o. group and groups receiving control solutions is statistically significant and has been discussed elsewhere (Giehl and Tetzlaff, 1996; Giehl et al., 1998).

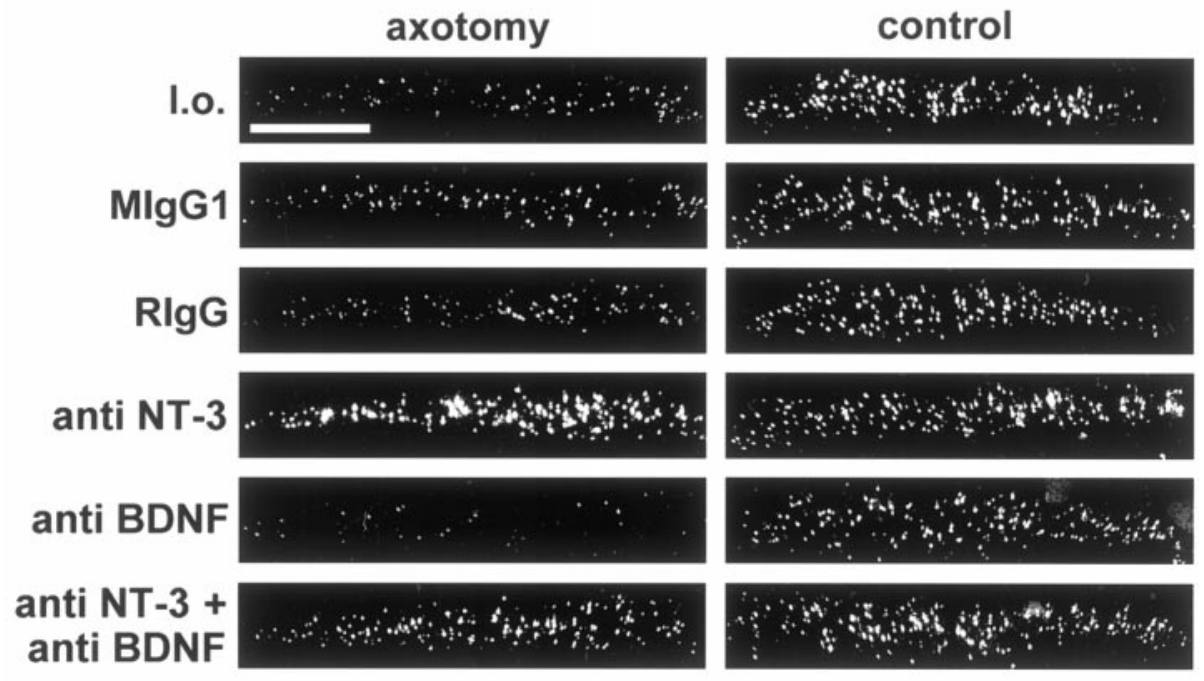

This finding further shows that the two neurotrophins have opposing effects on the survival of all BDNF-dependent CSNs.

\section{Axotomized rat CSNs express p75 and trkC mRNA, and trkC expression is suppressed by high-dose NT-3 treatment}

Although survival promotion of neurotrophins is mediated by Trk receptors, their death-inducing activity is thought to be mediated via $775^{\mathrm{NTR}}$ receptor in the absence of signaling by the respective Trk receptor (Dechant and Barde, 1997; Kaplan and Miller, 1997). We have shown recently that virtually all lesioned CSNs express trkB mRNA (Giehl et al., 1998), consistent with the survival promotion of endogenous BDNF. To show whether axotomized CSNs display a neurotrophin receptor expression pattern compatible with the death promotion of endogenous NT-3, we analyzed the expression of p75 mRNA (Radeke et al., 1987) and trkC mRNA lacking an insert in the tyrosine kinase domain (Valenzuela et al., 1993) with semiquantitative in situ hybridizations within the first week after axotomy. Axotomyinduced death of CSNs occurs between days 3 and 4 after ICL, reaches a plateau by day 5 (Giehl and Tetzlaff, 1996), and does not further proceed later on (Giehl and Tetzlaff, 1996; Giehl et 
A
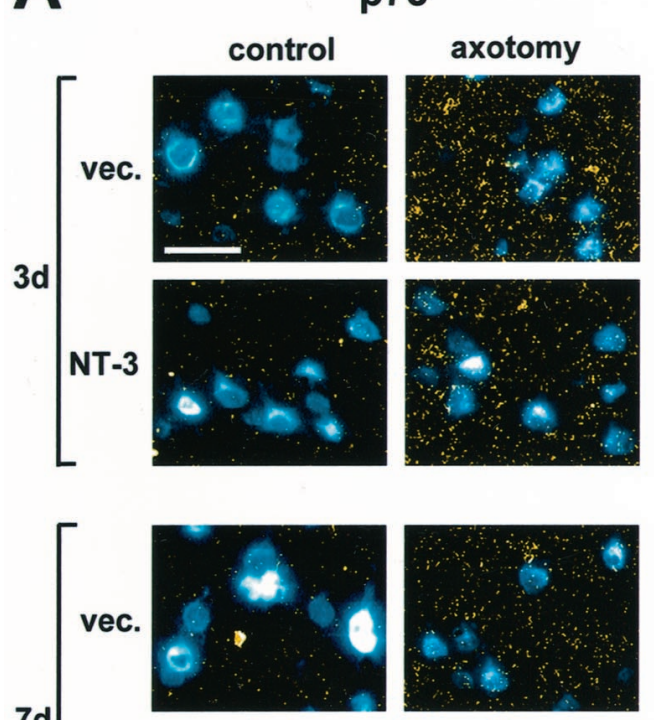

7d
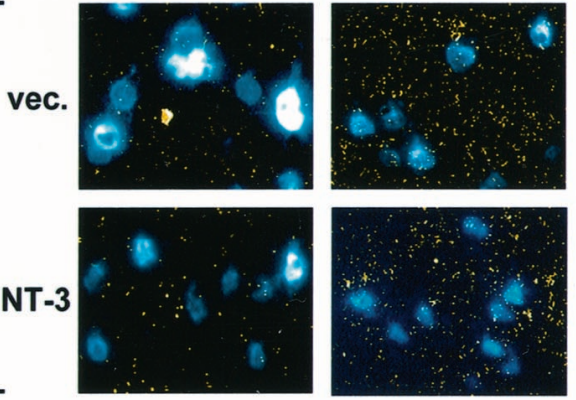

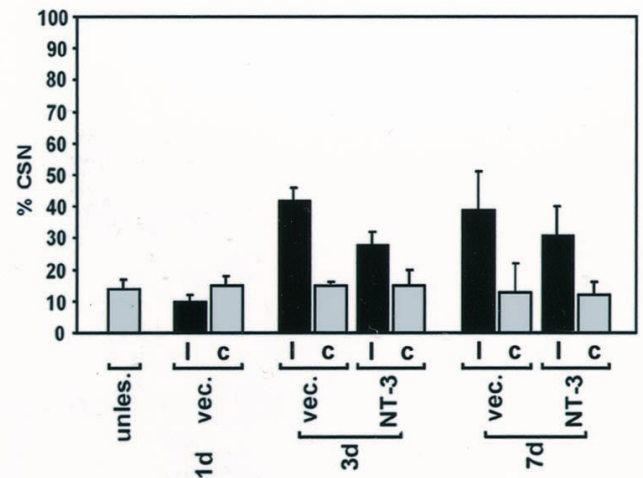

D

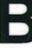

\section{$\%$ CSN expressing p75 mRNA}

trkC
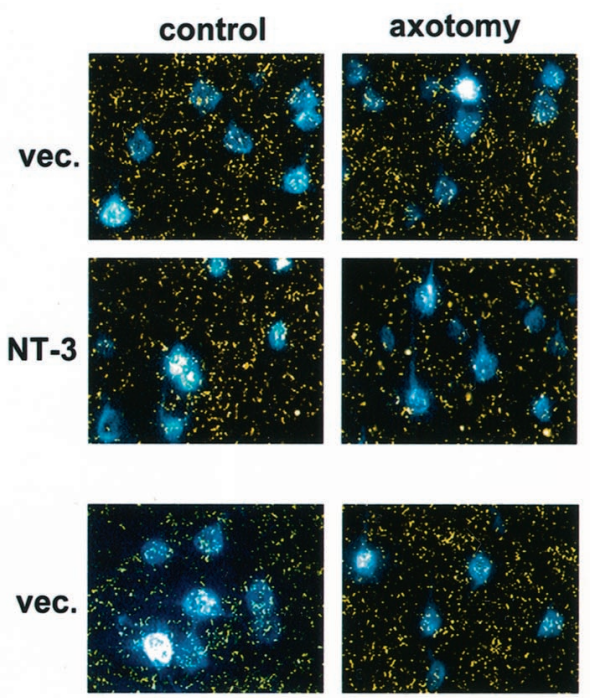

NT-3
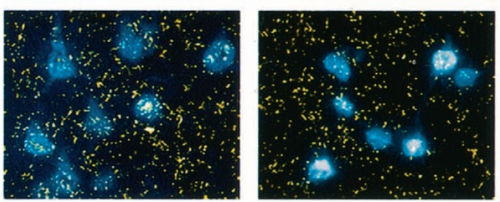

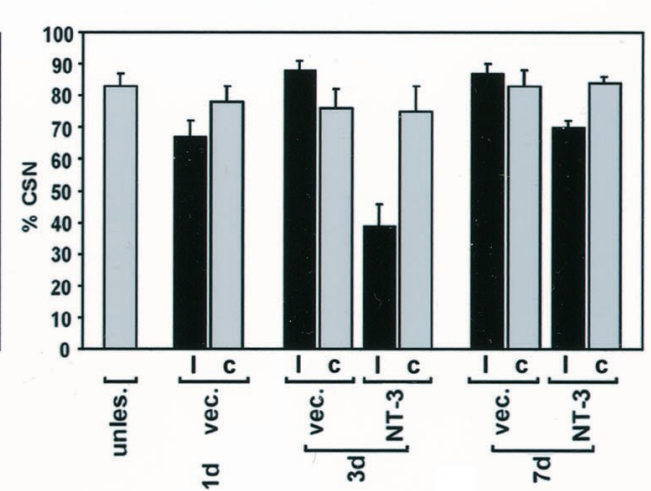

Figure 4. Expression of $\mathrm{p} 75$ and trkC mRNA in unlesioned and axotomized vehicle- and NT-3-treated CSNs. $A$, Double exposures of FB-labeled CSNs and autoradiograms of p75 and trkC ISHs at days 3 and 7 after axotomy. p75 expression is barely detectable in unlesioned CSNs but clearly upregulated by days 3 and 7 after axotomy. Infusion of NT-3 at a dose of $12 \mu \mathrm{g} / \mathrm{d}$ does not have an effect on p75 expression. Virtually all unlesioned and axotomized CSNs express trkC mRNA. Treatment with $12 \mu \mathrm{g} / \mathrm{d}$ NT-3 strongly suppresses trkC expression in axotomized CSNs at postlesion day 3 . Scale bar, 50 $\mu \mathrm{m}$. The p75 expression data were obtained with a probe complementary to nucleotides $932-971$ of the rat p75 mRNA. The same experiments (data not shown) have been performed with a probe complementary to nucleotides 1809-1848 of the rat p75 mRNA, which yielded essentially the same results. $B$, Quantification of p75 and trkC mRNA expression in CSNs (indicated is mean percentage of CSNs expressing a mRNA \pm SEM). Very few unlesioned CSNs $(n=6)$ express p75 mRNA. This expression pattern is not altered at day 1 after axotomy $(n=4)$. In contrast, the expression of p75 mRNA is induced in more than one-third of axotomized CSNs at day $3[n=6, p<0.01$ vs control adb NKT] and day 7 [ $n=4, p<0.05$ vs control adb NKT] after axotomy. There is a trend of reduced p75 mRNA expression in axotomized CSNs after NT-3 treatment at day 3 ( $n=4$, NS vs control adb FLSD at $p<0.05)$ and day $7(n=4$, NS vs control adb FLSD at $p<0.05)$. Virtually all CSNs express trkC mRNA in unlesioned animals $(n=6)$ or vehicle-treated animals at days $1(n=3), 3(n=5)$, and $7(n=5)$ after axotomy. NT-3 application significantly reduced the proportion of axotomized CSNs expressing trkC at day $3[n=4, p<0.01$ vs control adb NKT] but not at day $7[n=5$, NS adb FLST at $p<0.05]$ after axotomy. Black bars, Axotomized CSNs on the lesion sides of the cortices (l); gray bars, unlesioned animals or unlesioned CSNs of the control sides of the cortices $(c)$.

al., 1997). Thus, the receptor mRNA expression was assessed at days 1,3 , and 7 after axotomy. Virtually all CSNs expressed trkC at any time point (Fig. 4). Figure 4 further shows that many non-CSN cells express trkC mRNA. As revealed by cresyl violet staining (data not shown), this expression is mainly localized to pyramidal cells of cortical layer 5, but some of the label appeared to be derived from glia. In contrast to the robust expression of trkC, p75 was barely detectable in unlesioned CSNs or in CSNs at day 1 after axotomy, but it was clearly upregulated in axotomized CSNs at postlesion day 3 and later (Fig. 4). The time course of $\mathrm{p} 75$ expression suggests that $\mathrm{p} 75^{\mathrm{NTR}}$ receptor may be involved in the death induction of CSNs. Noncorticospinal cells of cortical 
layer 5 on the lesion side have higher p75 levels than CSNs, indicating that ICL leads to a general increase of p75 expression on the axotomy side (Fig. 4). As revealed by cresyl violet counterstaining (data not shown), this p75 expression is mainly localized to pyramidal-shaped neurons of cortical layer 5, suggesting that these noncorticospinal cells are subcortically projecting neurons that have been axotomized by the internal capsule lesion. Whether these cells contribute to the death of CSNs is not clear.

Treatment with exogenous recombinant NT-3 at doses of 12 $\mu \mathrm{g} / \mathrm{d}$ promotes survival (Giehl and Tetzlaff, 1996), whereas endogenous NT-3 induces death of axotomized CSNs. The survival-promoting effect of NT-3 treatment may be explained by mimicking BDNF action e.g., through TrkB activation caused by the unphysiologically high dose of NT-3 (Davies et al., 1995; Ryden and Ibanez, 1996) and/or increasing cortical BDNF expression. Alternatively, these inf usions might alter the expression of the receptor or receptors involved in survival and/or death signaling in axotomized CSNs. The first possibility is supported by previous findings that the effects of NT-3 inf usions are at least partially mediated by endogenous BDNF (Giehl et al., 1998) and that NT-3 treatment clearly increases BDNF mRNA expression in cortical layers 2-4, whereas trkB expression in CSNs is unaffected (Schütte et al., 2000). To show whether NT-3 treatment affects the expression of neurotrophin receptors potentially involved in the NT-3-mediated survival regulation of lesioned CSNs, we analyzed the expression of p75 and trkC in axotomized CSNs treated with $12 \mu \mathrm{g} / \mathrm{d}$ of recombinant NT-3. Although p 75 expression was not significantly altered by this NT-3 treatment, the portion of CSNs expressing trkC was clearly decreased at day 3 and largely recovered by day 7 (Fig. 4). These data suggest that the survival-promoting effect of high-dose NT-3 treatment is not mediated by TrkC but is also not explained by the downregulation of $\mathrm{p} 75$. We wondered whether changes in the relative levels of trkC isoforms might be relevant for trkC-dependent neuronal death in NT-3 and vehicle-treated animals. RT-PCR with primers on both sides of the kinase insert demonstrated the presence of all kinase insert forms (14, 25, and 39 amino acids) together with the insertless kinase, but failed to reveal any alterations in the relative levels of these isoforms (data not shown). We finally directly assessed TrkB activation by exogenous NT-3 by directly measuring cortical TrkB phosphorylation after high-dose NT-3 treatment. Indeed, intracortical injections of high doses of NT-3 induce TrkB phosphorylation as early as $1 \mathrm{hr}$ after administration (Fig. 5A). Together, these findings suggest that the effects of our previously reported NT-3 treatment (Giehl and Tetzlaff, 1996) do not reflect the physiological role of NT-3 for CSNs but rather a mimicry of endogenous BDNF function.

\section{Death of axotomized rat CSNs depends on cosignaling of $\mathrm{p} 75$ and trkC receptors}

The p75 and trkC mRNA expression patterns in untreated and NT-3-treated lesioned CSNs suggest a mechanism of NT-3mediated death induction different from previous reports (Frade et al., 1996; Bamji et al., 1998) in which a neurotrophin mediates neuronal death via $\mathrm{p} 75^{\mathrm{NTR}}$ receptor in the absence of its Trk receptor. To determine which receptors are involved in the death induction, we treated axotomized rat CSNs with monovalent Fab fragments of the rabbit REX antibody (REX-Fab) (Weskamp and Reichardt, 1991) against $\mathrm{p} 75^{\mathrm{NTR}}$ and with the rabbit TrkC antibody TC89. REX has been shown to specifically bind to and block the p75 receptor (Weskamp and Reichardt, 1991). Similarly,
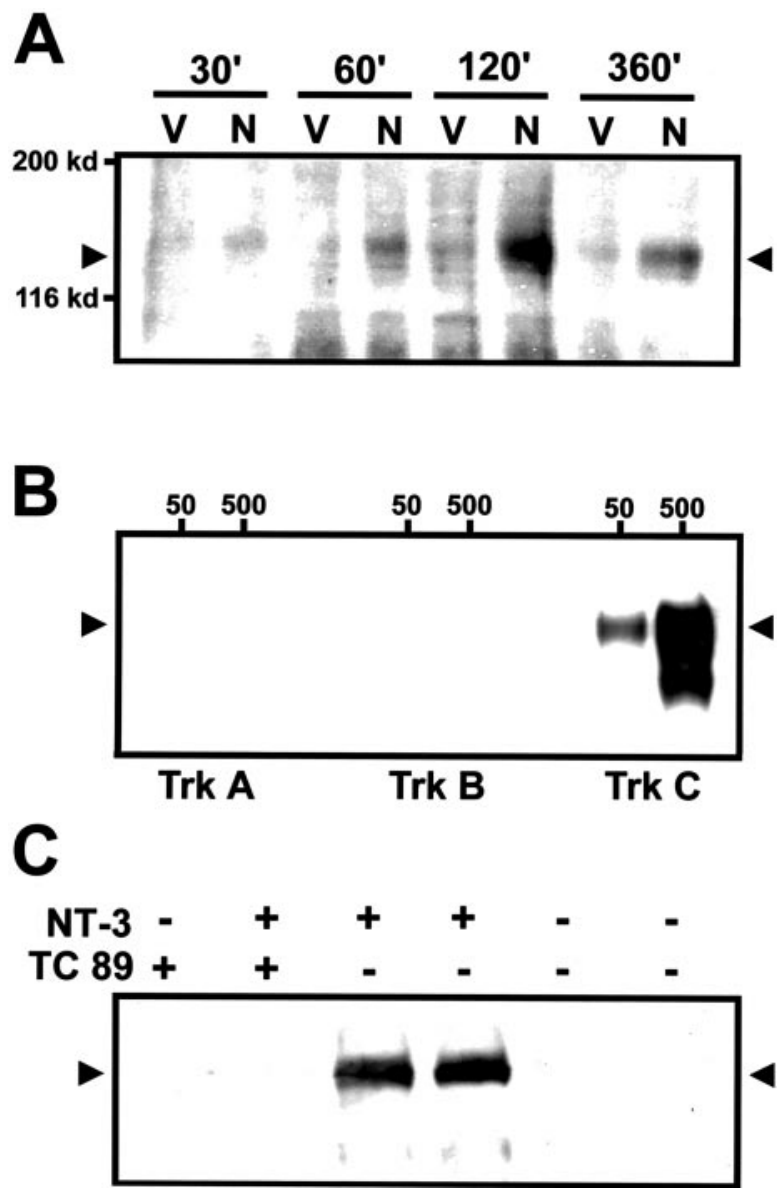

Figure 5. A, Intracortical high-dose NT-3 injections induce cortical TrkB phosphorylation. TrkB Western blots of electrophoresed anti-phosphotyrosine immunoprecipitates of homogenates of vehicle $(V)$ - or $500 \mathrm{ng} / \mu \mathrm{l}$ NT-3 $(N)$-treated rat cortices $30,60,120$, and 360 min after $10 \mu$ injection of the respective solution. The arrowheads indicate the position of TrkB. $B$, TC89 specifically binds to TrkC. In Western blots of 50 (lanes labeled 50) or $500 \mathrm{ng}$ (lanes labeled 500) of the extracellular domains of each recombinant Trk protein per lane, TC 89 recognizes TrkC, and there was no crossreactivity to TrkA or TrkB. The arrowheads indicate the position of the encoded recombinant Trk proteins (Yan et al., 1997a). C, TC89 inhibits NT-3-induced phosphorylation of TrkC. TrkC-transfected NIH 3T3 cells were exposed to NT-3 (+), TC89 (+), or both for $10 \mathrm{~min}$. TrkC phosphorylation was seen after NT-3 treatment but completely abolished by TC89. Also, TC89 alone had no effect on TrkC phosphorylation. The arrowhead indicates the position of the trkC product.

TC89 only recognizes the extracellular domain of TrkC, but not of TrkA and TrkB and completely blocks NT-3-induced TrkC phosphorylation without having detectable agonist-like effects on this receptor (Fig. 5B,C). The intracortical treatment of lesioned animals with these antibodies started immediately after ICL and lasted for $7 \mathrm{~d}$. Axotomy-induced death of CSNs was prevented in animals treated either alone with REX-Fab or alone with TC89 (Fig. 6). These data argue that both $\mathrm{p} 75^{\mathrm{NTR}}$ and TrkC signaling are essential for the induction of CSN death.

\section{DISCUSSION}

This study shows that endogenous BDNF and NT-3 antagonistically regulate survival of lesioned adult CSNs in vivo. Death is induced by endogenous NT-3 and requires activation of TrkC and cosignaling of $\mathrm{p} 75^{\mathrm{NTR}}$, demonstrating that mature central neu- 


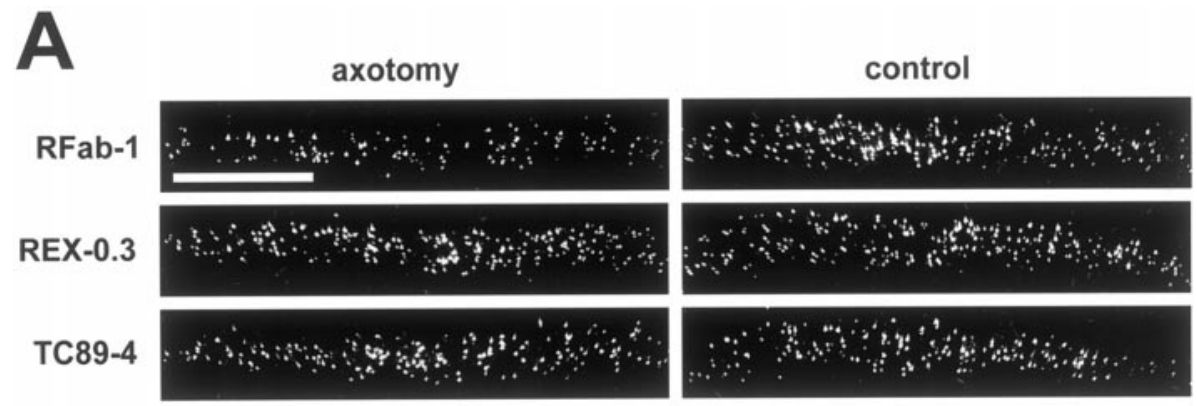

B

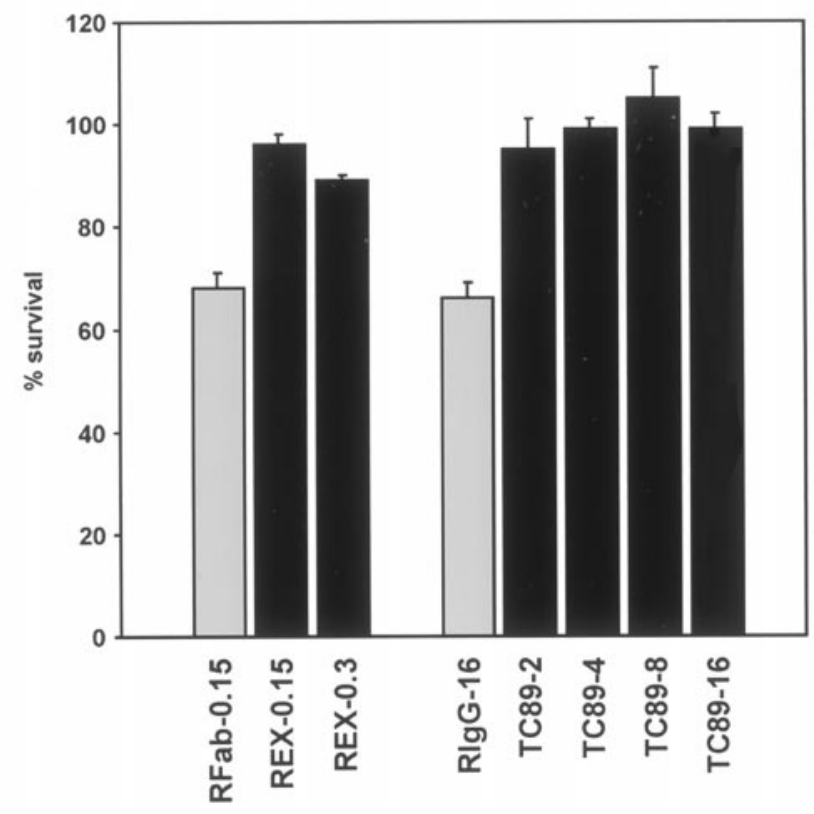

Figure 6. Death of axotomized CSNs is mediated via essential coactivation of TrkC and $\mathrm{p} 75$ receptors. A, FB-labeled CSNs of lesion and control sides of representative animals of a control group [rabbit monovalent Fab fragments, $1 \mathrm{mg} / \mathrm{ml}$ (RFab-1)] and the groups receiving receptorblocking antibodies [p75 antibody, $0.3 \mathrm{mg} / \mathrm{ml}$ (REX-0.3); TrkC antibody; $4 \mathrm{mg} / \mathrm{ml}$ (TC89-4)]. Application of control rabbit Fab (RFab-1) results in death of CSNs comparable with other control solutions (Fig. 3). Treatment with either REXFab or TC89 IgG alone prevents axotomy-induced death of CSNs. Scale bar, $1 \mathrm{~mm}$. B, Quantification of survival of axotomized CSNs (indicated is mean survival \pm SEM). One-third of the CSNs of the control groups [monovalent rabbit Fab, 1 $\mathrm{mg} / \mathrm{ml}(R F a b-1 ; n=2)$ and $0.15 \mathrm{mg} / \mathrm{ml}(R F a b-$ $0.15 ; n=4)$; rabbit IgG, $1 \mathrm{ml} / \mathrm{ml}(R \operatorname{IgG}-1 ; n=5)$ (Fig. 1), and $16 \mathrm{mg} / \mathrm{ml}(R \operatorname{IgG}-16 ; n=2)$; P2 buffer $(69 \pm 2 \% ; n=3$; data not shown)] die within the first week after axotomy. This death is completely prevented by application of either REX-Fab $[0.15$ $\mathrm{mg} / \mathrm{ml}$ (REX-0.15, $n=5, p<0.01$ vs $\mathrm{P} 2$ and RFab-0.15 adb NKT, $p<0.05$ vs RFab-1 adb $\mathrm{NKT})$ and $0.3 \mathrm{mg} / \mathrm{ml}$ (REX-0.3, $n=3, p<0.05 \mathrm{vs}$ all control groups adb NKT)] or TC89 [2 $($ TC89-2l $n=3), 4($ TC89-41 $n=4), 8($ TC89-8; $n=4)$, and $16 \mathrm{mg} / \mathrm{ml}$ (TC89-16; $n=3), p<0.01$ vs all control groups adb NKT)]. The data in this figure argue that activation of both $\mathrm{p} 75$ and TrkC is required for the induction of death in CSNs. rons can integrate multiple neurotrophin-dependent signals for death and survival decisions.

Although previous reports have not found gross morphological alterations of the cortex or the corticospinal tract in mice mutant for BDNF, NT-3, and their receptors (Klein et al., 1993; Ernfors et al., 1994a,b; Farinas et al., 1994; Jones et al., 1994; Klein et al., 1994), several aspects of cortical development are regulated by endogenous BDNF and NT-3. BDNF has been implicated in the development of cortical lamination (Ringstedt et al., 1998), and NT-3 influences axonal growth of cortical neurons (Castellani and Bolz, 1999). In addition, both neurotrophins regulate the dendritic development of cortical pyramidal neurons (McAllister et al., 1997). We found that neither the number nor the localization of corticospinal neurons was altered in young adult heterozygous BDNF and NT-3 mutants. Thus, the reduced levels of these neurotrophins in heterozygotes (Ernfors et al., 1994a,b; Korte et al., 1995; Airaksinen et al., 1996) (C. Helbig and M. Meyer, unpublished data) appear to be sufficient for normal development. To further exclude the possibility that results from axotomized mutant mice are obscured by developmental alterations, we also acutely depleted neurotrophins using antibodies in rats. Conclusions from both types of experiments are very similar.

These data confirm our previous notion that endogenous BDNF is crucial for survival promotion of the majority of lesioned adult CSNs (Giehl et al., 1998). In contrast, endogenous NT-3 is a critical component of lesion-induced death signaling in axotomized CSN, despite our earlier work showing that exogenous NT-3, as well as BDNF, promote their survival (Giehl and Tetzlaff, 1996). How can these results be reconciled? Most importantly, there is an obvious difference in the experimental approach. Here, endogenous NT-3 was depleted, whereas in the previous study, high doses of NT-3 were intracortically infused. High concentrations of NT-3 are known to evoke effects similar to BDNF by activating TrkB as a nonpreferred receptor (Davies et al., 1995; Ryden and Ibanez, 1996) or by inducing BDNF release (Canossa et al., 1997; Kruttgen et al., 1998). We have previously shown that the complete rescue of lesioned CSNs by NT-3-infusions (Giehl and Tetzlaff, 1996) depends on endogenous BDNF (Giehl et al., 1998) and that these infusions increase cortical BDNF mRNA expression (Schütte et al., 2000). In addition, we show here that a high dose of exogenous NT-3 reduces the number of trkC-expressing CSNs and results in cortical TrkB phosphorylation. Thus, high-dose NT-3 treatment may promote survival by evoking BDNF-like effects and stimulating endogenous BDNF, and, at the same time, also counteract death by reduced expression of death-mediating receptor or receptors. The prediction that low NT-3 concentrations will enhance death of axotomized CSNs is valid only if the effects of endogenous NT-3 are submaximal. We have tested this possibility in a limited number of experiments (data not shown), and even NT-3 treatment at doses as low as $0.06 \mathrm{ng} / \mathrm{hr}$ did not yield lower survival than vehicle application. This result is compatible with the as- 
sumption that endogenous NT-3 levels are sufficient for a maximal effect. However, limited diff usion or stability of NT-3 at very low doses may have hindered its effects. Furthermore, the function of NT-3 may depend on the way of its presentation as previously demonstrated in the chick visual system (Frade and Barde, 1998). A clear answer to this specific question requires administration of NT-3 alone and in combination with antiBDNF into the cortex of animals devoid of endogenous NT-3 and, therefore, has to await the availability of cortex-specific conditional mutants.

According to the classical neurotrophin hypothesis, survival of neurons is regulated by their limited access to survival-promoting substances (Lewin and Barde, 1996). This hypothesis has been significantly modified by the recent findings that endogenous NGF (Frade et al., 1996, 1997; Frade and Barde, 1998; Davey and Davies, 1998) and BDNF (Bamji et al., 1998) can induce neuronal death via $\mathrm{p} 75^{\mathrm{NTR}}$ receptors during development. Previous evidence that exogenous trophic factors promote survival of neurons that are killed by another endogenous neurotrophin (Frade et al., 1997; Davey and Davies, 1998) suggests that a neurotrophin antagonism might regulate neuronal survival. The present finding of opposite effects of endogenous NT-3 and BDNF on the survival of one neuronal population demonstrates that endogenous neurotrophins can indeed antagonistically regulate neuronal survival in vivo. In addition, our data provide evidence that neurotrophins can induce neuronal death in the mature CNS.

The observation that axotomized CSNs survive simultaneous depletion of BDNF and NT-3 suggests that the NT-3-mediated death signal is functionally dominant. It is unlikely that other neurotrophins can substitute for BDNF in this situation. Of the known neurotrophins, NT-4/5 is, like BDNF and NT-3, expressed in the mature cortex (Timmusk et al., 1993). It acts via TrkB and has higher affinity to this receptor than NT-3 (Barbacid, 1995). Because BDNF neutralization alone clearly enhances death of axotomized CSN, it is unlikely that endogenous NT-4/5 significantly promotes their survival. The question arises why there should be a survival-supporting signal if the amount of cell death can be determined by endogenous NT-3? Considering the pleiotrophic roles of BDNF and NT-3 for cortical neurons (Schnell et al., 1994; McAllister et al., 1997; Castellani and Bolz, 1999), endogenous NT-3 may regulate additional aspects of CSN biology and, therefore, its effects on survival have to be regulated in accordance with these roles.

There are three striking features of the NT-3-dependent death pathway for axotomized CSNs in vivo. First, NT-3 controls survival of virtually all BDNF-dependent CSNs. This single factor could in principle be altered to precisely titrate the number of dying neurons. Second, the essential players for cell death promotion are locally present before and after lesion: NT-3 is expressed in the unlesioned and lesioned cortex (Ernfors et al., 1990; Altar et al., 1994; Zhou and Rush, 1994) (K. Giehl and W. Tetzlaff, unpublished observation), and virtually all unlesioned (Giehl and Tetzlaff, 1996) and lesioned CSNs express trkC. Similarly, the BDNF-TrkB pathway is also present in cortex and CSNs and not altered by axotomy (Giehl et al., 1998; Schütte et al., 2000). In addition to their neuronal expression in the cortex, there are other potentially relevant sources of endogenous BDNF and NT-3, e.g., cortical astrocytes (Rubio, 1997), the cortical white matter and the internal capsule, and several brainstem areas (Ernfors et al., 1990; Altar et al., 1994; Zhou and Rush, 1994).
Finally, significant p75 expression in CSNs is only observed at day 3 and later after axotomy. Thus, the onset of p75 expression may control the timing of CSN death. The p $75^{\mathrm{NTR}}$ signal is probably ligand-induced because REX antibody has been described to inhibit ligand binding to p75 ${ }^{\mathrm{NTR}}$ (Weskamp and Reichardt, 1991). Because exogenous (Giehl and Tetzlaff, 1996) as well as endogenous (S. Röhrig, M. Meyer, and K. Giehl, unpublished data) NGF does not seem to play a role in this context, NT-3 is the most likely ligand for the $\mathrm{p} 75^{\mathrm{NTR}}$-mediated death induction of CSNs. We can, however, not exclude that constitutive p75 NTR signaling (Majdan et al., 1997) contributes to this effect.

How does the NT-3-TrkC pathway relate to known neurotrophin-mediated death mechanisms? To our knowledge, there is no previous report involving an action of NT-3 via TrkC in cell death promotion in vivo. There is, however, an intriguing account of death induction of NT-3 via TrkC in medulloblastomas (Kim et al., 1999). Interestingly, death induction in medulloblastomas can also be triggered by NGF through TrkA (Muragaki et al., 1997), suggesting that this effect is not specific for TrkC. Thus, there is apparently no need to invoke the induction of specific TrkC receptor isoforms (Valenzuela et al., 1993; Tsoulfas et al., 1996) as being more prone to death signaling. This conclusion is supported by our analysis of the expression of these isoforms in lesioned cortex.

The necessity of $\mathrm{p} 75^{\mathrm{NTR}}$ and TrkC cosignaling for death induction could be explained by two principally different models. Both receptors could be involved in death signaling, and the observed interdependence could be accounted for by a threshold for efficient death induction, which is not reached by $\mathrm{p} 75^{\mathrm{NTR}}$ or TrkC signaling alone. This is in line with the observation that TrkC and $\mathrm{p} 75^{\mathrm{NTR}}$ receptors can be coimmunoprecipitated (Bibel et al., 1999). Alternatively, one of the receptors may be required as a conditioning signal. Because endogenous NT-3 induces neuronal differentiation of cortical precursors which, after adopting a neuronal phenotype, are dependent on endogenous BDNF for survival (Ghosh et al., 1994; Ghosh and Greenberg, 1995), one conceivable scenario states that NT-3 signaling via TrkC is constantly required to maintain BDNF dependence of CSNs. In this case, $\mathrm{p} 75^{\mathrm{NTR}}$ signaling would induce death of those CSNs that do not receive sufficient BDNF to allow survival. Our observation that CSNs are rescued from axotomy-induced death by simultaneous depletion of endogenous BDNF and NT-3 is in accordance with this possibility. It will be important to unravel the mechanisms underlying this regulation in subsequent studies. In this context, it will be of central interest to determine whether the BDNF-NT-3-mediated antagonism on CSN survival represents a pure and direct trophic action on $\mathrm{CSNs}$ or involves additional molecules and/or cell types.

\section{REFERENCES}

Airaksinen MS, Koltzenburg M, Lewin GR, Masu Y, Helbig C, Wolf E, Brem G, Toyka KV, Thoenen H, Meyer M (1996) Specific subtypes of cutaneous mechanoreceptors require neurotrophin-3 following peripheral target innervation. Neuron 16:287-295.

Altar CA, Siuciak JA, Wright P, Ip N Y, Lindsay RM, Wiegand SJ (1994) In situ hybridization of trkB and trkC receptor mRNA in rat forebrain and association with high-affinity binding of [125I]BDNF, [125I]NT-4/5 and [125I]NT-3. Eur J Neurosci 6:1389-1405.

Bamji SX, Majdan M, Pozniak CD, Belliveau DJ, Aloyz R, Kohn J, Causing CG, Miller FD (1998) The p75 neurotrophin receptor mediates neuronal apoptosis and is essential for naturally occurring sympathetic neuron death. J Cell Biol 140:911-923.

Barbacid M (1995) Neurotrophic factors and their receptors. Curr Opin Cell Biol 7:148-155.

Barres BA, Raff MC, Gaese F, Bartke I, Dechant G, Barde YA (1994) A 
crucial role for neurotrophin-3 in oligodendrocyte development. $\mathrm{Na}$ ture 367:371-375.

Bibel M, Hoppe E, Barde YA (1999) Biochemical and functional interactions between the neurotrophin receptors trk and p75NTR. EMBO J 18:616-622.

Bonatz H, Röhrig S, Mestres P, Meyer M, Giehl KM (2000) An axotomy model for the induction of death of rat and mice corticospinal neurons in vivo. J Neurosci Methods 100:105-115.

Botchkina GI, Meistrell ME 3rd, Botchkina IL, Tracey KJ (1997) Expression of TNF and TNF receptors (p55 and p75) in the rat brain after focal cerebral ischemia. Mol Med 3:765-781.

Canossa M, Griesbeck O, Berninger B, Campana G, Kolbeck R, Thoenen H (1997) Neurotrophin release by neurotrophins: implications for activity-dependent neuronal plasticity. Proc Natl Acad Sci USA 94:13279-13286.

Castellani V, Bolz J (1999) Opposing roles for neurotrophin-3 in targeting and collateral formation of distinct sets of developing cortical neurons. Development 126:3335-3345.

Davey F, Davies AM (1998) TrkB signalling inhibits p75-mediated apoptosis induced by nerve growth factor in embryonic proprioceptive neurons. Curr Biol 8:915-918.

Davies AM, Minichiello L, Klein R (1995) Developmental changes in NT3 signalling via TrkA and TrkB in embryonic neurons. EMBO J 14:4482-4489.

Dechant G, Barde YA (1997) Signalling through the neurotrophin receptor p75NTR. Curr Opin Neurobiol 7:413-418.

Ernfors P, Wetmore C, Olson L, Persson H (1990) Identification of cells in rat brain and peripheral tissues expressing mRNA for members of the nerve growth factor family. Neuron 5:511-526.

Ernfors P, Lee KF, Jaenisch R (1994a) Mice lacking brain-derived neurotrophic factor develop with sensory deficits. Nature 368:147-150.

Ernfors P, Lee KF, Kucera J, Jaenisch R (1994b) Lack of neurotrophin-3 leads to deficiencies in the peripheral nervous system and loss of limb proprioceptive afferents. Cell 77:503-512.

Farinas I, Jones KR, Backus C, Wang XY, Reichardt LF (1994) Severe sensory and sympathetic deficits in mice lacking neurotrophin-3. Nature 369:658-661.

Frade JM, Barde YA (1998) Microglia-derived nerve growth factor causes cell death in the developing retina. Neuron 20:35-41.

Frade JM, Rodriguez Tebar A, Barde YA (1996) Induction of cell death by endogenous nerve growth factor through its p 75 receptor. Nature 383:166-168.

Frade JM, Bovolenta P, Martinez Morales JR, Arribas A, Barbas JA, Rodriguez Tebar A (1997) Control of early cell death by BDNF in the chick retina. Development 124:3313-3320.

Ghosh A, Greenberg ME (1995) Distinct roles for bFGF and NT-3 in the regulation of cortical neurogenesis. Neuron 15:89-103.

Ghosh A, Carnahan J, Greenberg ME (1994) Requirement for BDNF in activity-dependent survival of cortical neurons. Science 263:1618-1623.

Giehl K, Mestres P (1995) Somatostatin-mRNA expression in brainstem projections into the medial preoptic nucleus. Exp Brain Res 103:344-354.

Giehl KM, Tetzlaff W (1996) BDNF and NT-3, but not NGF, prevent axotomy induced death of rat corticospinal neurons in vivo. Eur J Neurosci 8:1167-1175.

Giehl KM, Schacht CM, Yan Q, Mestres P (1997) GDNF is a trophic factor for adult rat corticospinal neurons and promotes their long-term survival after axotomy in vivo. Eur J Neurosci 9:2479-2488.

Giehl KM, Schutte A, Mestres P, Yan Q (1998) The survival-promoting effect of glial cell line-derived neurotrophic factor on axotomized corticospinal neurons in vivo is mediated by an endogenous brainderived neurotrophic factor mechanism. J Neurosci 18:7351-7360.

Jones EG, Schreyer DJ, Wise SP (1982) Growth and maturation of the rat corticospinal tract. Prog Brain Res 57:361-379.

Jones KR, Farinas I, Backus C, Reichardt LF (1994) Targeted disruption of the brain-derived neurotrophic factor gene perturbs brain and sensory neuron but not motor neuron development. Cell 76:989-1000.

Kaplan DR, Miller FD (1997) Signal transduction by the neurotrophin receptors. Curr Opin Cell Biol 9:213-221.

Kim JY, Sutton ME, Lu DJ, Cho TA, Goumnerova LC, Goritchenko L, Kaufman JR, Lam KK, Billet AL, Tarbell NJ, Wu J, Allen JC, Stiles CD, Segal RA, Pomeroy SL (1999) Activation of neurotrophin-3 receptor TrkC induces apoptosis in medulloblastomas. Cancer Res 59:711-719.

Klein R, Smeyne RJ, Wurst W, Long LK, Auerbach BA, Joyner AL, Barbacid M (1993) Targeted disruption of the trkB neurotrophin receptor gene results in nervous system lesions and neonatal death. Cell 75:113-122.

Klein R, Silos Santiago I, Smeyne RJ, Lira SA, Brambilla R, Bryant S, Zhang L, Snider WD, Barbacid M (1994) Disruption of the neurotrophin-3 receptor gene trkC eliminates la muscle afferents and results in abnormal movements. Nature 368:249-251.

Korte M, Carroll P, Wolf E, Brem G, Thoenen H, Bonhoeffer T (1995)
Hippocampal long-term potentiation is impaired in mice lacking brainderived neurotrophic factor. Proc Natl Acad Sci USA 92:8856-8860.

Kruttgen A, Moller JC, Heymach Jr JV, Shooter EM (1998) Neurotrophins induce release of neurotrophins by the regulated secretory pathway. Proc Natl Acad Sci USA 95:9614-9629.

Lewin GR, Barde YA (1996) Physiology of the neurotrophins. Annu Rev Neurosci 19:289-317.

Majdan M, Lachance C, Gloster A, Aloyz R, Zeindler C, Bamji S, Bhakar A, Belliveau D, Fawcett J, Miller FD, Barker PA (1997) Transgenic mice expressing the intracellular domain of the p75 neurotrophin receptor undergo neuronal apoptosis. J Neurosci 17:6988-6998.

McAllister AK, Katz LC, Lo DC (1997) Opposing roles for endogenous BDNF and NT-3 in regulating cortical dendritic growth. Neuron 18:767-778.

McCabe JT, Desharnais RA, Pfaff DW (1989) Graphical and statistical approaches to data analysis for in situ hybridization. Methods Enzymol 168:822-848

Miller MW (1987) The origin of corticospinal projection neurons in rat. Exp Brain Res 67:339-351.

Miller MW, Pitts FA (2000) Neurotrophin receptors in the somatosensory cortex of the mature rat: co-localization of p75, trk isoforms and c-neu. Brain Res 852:355-366.

Muragaki Y, Chou TT, Kaplan DR, Trojanowski JQ, Lee VM (1997) Nerve growth factor induces apoptosis in human medulloblastoma cell lines that express TrkA receptors. J Neurosci 17:530-542.

Nudo RJ, Masterton RB (1990) Descending pathways to the spinal cord, III: Sites of origin of the corticospinal tract. J Comp Neurol 296:559-583.

Nudo RJ, Sutherland DP, Masterton RB (1995) Variation and evolution of mammalian corticospinal somata with special reference to primates. J Comp Neurol 358:181-205.

O'Leary DDM, Koester SE (1993) Development of projection neuron types, axon pathways, and patterned connections of the mammalian cortex. Neuron 10:991-1006.

Offenhäuser N, Böhm-Matthaei R, Tsoulfas P, Parada L, Meyer M (1995) Developmental regulation of full-length trkC in the rat sciatic nerve. Eur J Neurosci 7:917-925.

Oudega M, Varon S, Hagg T (1994) Distribution of corticospinal motor neurons in the postnatal rat: quantitative evidence for massive collateral elimination and modest cell death. J Comp Neurol 347:115-126.

Pitts AF, Miller MW (2000) Expression of nerve growth factor, brainderived neurotrophic factor, and neurotrophin-3 in the somatosensory cortex of the mature rat: coexpression with high-affinity neurotrophin receptors. J Comp Neurol 418:241-254.

Radeke MJ, Misko TP, Hsu C, Herzenberg LA, Shooter EM (1987) Gene transfer and molecular cloning of the rat nerve growth factor receptor. Nature 325:593-597.

Rimm DL, Pollard TD (1989) New plasmid vectors for high level synthesis of eukaryotic fusion proteins in Escherichia coli. Gene 75:323-327.

Ringstedt T, Linnarsson S, Wagner J, Lendahl U, Kokaia Z, Arenas E, Ernfors P, Ibanez CF (1998) BDNF regulates reelin expression and Cajal-Retzius cell development in the cerebral cortex. Neuron 21:305-315.

Rogers AW (1979) Techniques of autoradiography. Amsterdam: Elsevier.

Roux PP, Colicos MA, Barker PA, Kennedy TE (1999) p75 neurotrophin receptor expression is induced in apoptotic neurons after seizure. J Neurosci 19:6887-6896.

Rubio N (1997) Mouse astrocytes store and deliver brain-derived neurotrophic factor using non-catalytic gp95trkB receptor. Eur J Neurosci 9:1847-1853.

Ryden M, Ibanez CF (1996) Binding of neurotrophin-3 to p75LNGFR, TrkA, and TrkB mediated by a single functional epitope distinct from that recognized by trkC. J Biol Chem 271:5623-5627.

Schnell L, Schneider R, Kolbeck R, Barde YA, Schwab ME (1994) Neurotrophin-3 enhances sprouting of corticospinal tract during development and after adult spinal cord lesion. Nature 367:170-173.

Schütte A, Yan Q, Mestres P, Giehl KM (2000) The endogenous survival promotion of axotomized corticospinal neurons by BDNF is mediated via paracrine, rather than autocrine mechanisms. Neurosci Lett 290:185-188.

Shi B, Mocchetti I (2000) Dexamethasone induces TrkA and p74 immunoreactivity in the cerebral cortex and hippocampus. Exp Neurol 162:257-267.

Tessarollo L, Vogel KS, Palko ME, Reid SW, Parada LF (1994) Targeted mutation in the neurotrophin-3 gene results in loss of muscle sensory neurons. Proc Natl Acad Sci USA 91:11844-11848.

Timmusk T, Belluardo N, Metsis M, Persson H (1993) Widespread and developmentally regulated expression of neurotrophin-4 mRNA in rat brain and peripheral tissues. Eur J Neurosci 5:605-613. 
Tsoulfas P, Stephens RM, Kaplan DR, Parada LF (1996) TrkC isoforms with inserts in the kinase domain show impaired signaling responses. J Biol Chem 271:5691-5697.

Uematsu J, Ono K, Yamano T, Shimada M (1996) Development of corticospinal tract fibers and their plasticity I: quantitative analysis of the developing corticospinal tract in mice. Brain Dev 18:29-34.

Valenzuela DM, Maisonpierre PC, Glass DJ, Rojas E, Nunez L, Kong Y, Gies DR, Stitt TN, Ip NY, Yancopoulos GD (1993) Alternative forms of rat TrkC with different functional capabilities. Neuron 10:963-974.

Weskamp G, Reichardt LF (1991) Evidence that biological activity of NGF is mediated through a novel subclass of high affinity receptors. Neuron 6:649-663.
Wu W, Mathew TC, Miller FD (1993) Evidence that the loss of homeostatic signals induces regeneration-associated alterations in neuronal gene expression. Dev Biol 158:456-466.

Yan Q, Radeke MJ, Metheson CR, Talvenheimo J, Welcher AA, Feinstein SC (1997a) Immunocytochemical localization of TrkB in the central nervous system of the adult rat. J Comp Neurol 378:135-157.

Yan Q, Rosenfeld RD, Matheson CR, Hawkins N, Lopez OT, Bennet L, Welcher AA (1997b) Expression of brain-derived neurotrophic factor (BDNF) in the adult rat central nervous system. Neuroscience 78:431-448.

Zhou X-F, Rush RA (1994) Localization of neurotrophin-3-like immunoreactivity in the rat central nervous system. Brain Res 643:162-172. 